\title{
Influence of The -202 A/C insulin-like growth factor- binding protein-3 promoter polymorphism on individual variation in height in Korean girls
}

\author{
Min Ju Yi, MD, \\ Tae Young Park, MD, \\ II Tae Hwang, MD, \\ Seung Yang, MD
}

Department of Pediatrics, Hallym University College of Medicine, Seoul, Korea
Received: 5 August, 2016 Revised: 29 August, 2016 Accepted: 20 September, 2016

Address for correspondence: Seung Yang, MD

Department of Pediatrics, Hallym University College of Medicine, 1 Hallimdaehak-gil, Chuncheon 24252, Korea

Tel: +82-2-2224-2251

Fax: +82-2-2224-2496

E-mail: drsyang@hallym.or.kr

https://orcid.org/0000-0002-33806962
Purpose: The most common single nucleotide polymorphism in the IGFBP3 promoter region occurs at position -202. This polymorphic variation occurs frequently and may influence growth hormone responsiveness and somatic growth. However, the effects of IGFBP3 promoter polymorphism on growth in children are unknown.

Methods: Restriction fragment length polymorphism-based genotyping of the -202 single nucleotide polymorphism was performed in 146 Korean girls aged between 15 and 16 years, who were selected randomly from the Seoul School Health Promotion Center. The participants were divided into 3 groups (tall, medium, and short) according to the height percentile established from normal reference values for Korean children. The serum levels of insulin-like growth factor I (IGF-I) and IGFbinding protein-3 (IGFBP-3) were then compared according to genotype.

Results: The genotype distribution in the participants was 79 AA (54.1\%), 60 AC (41.1\%), and 7 CC (4.8\%). The $C$ allele frequency at the -202 IGFBP3 position was $25.4 \%$ in this group. The mean serum IGFBP-3 concentration in girls with the $A A$ genotype was higher than that in girls with the $A C$ genotype in the medium $(P=0.047)$ and short $(P=0.035)$ groups, respectively. There was no difference in the IGF-I to IGFBP-3 molar ratio between the AA and AC genotype groups $(P=0.161)$. Conclusion: In conclusion, the -202 polymorphism in the IGFBP3 promoter region is assumed to affect the serum concentration of IGFBP-3 in children as well as in adults. However, it is unclear whether this affects physical development according to the concentration of IGFBP-3.

Keywords: Body height, Insulin-like growth factor-binding protein 3, Polymorphism

\section{Introduction}

Insulin-like growth factor I (IGF-I) expression is regulated by growth hormone and is essential for somatic growth in children ${ }^{1)}$. Furthermore, it is known that serum levels of IGF-I and IGF-binding protein-3 (IGFBP-3) reflect spontaneous growth hormone secretion in healthy individuals ${ }^{2}$. Circulating IGF-I binds to IGFBP-3 to form a tertiary structure, while unbound, free IGF-I plays a role in target tissues. Because of the very short metabolic half-life of IGF-I, it is difficult to measure its precise serum level. Instead, the levels of free, biologically active IGF-I can be estimated by measuring the molar ratio between IGF-I and IGFBP-3, because IGFBP-3 is pivotal for circulating IGF bioactivity ${ }^{3}$. It has been speculated that higher levels of IGFBP-3 are associated with lower levels of free IGF-I in the serum, mainly because most IGF-I is bound to IGFBP-3. Five polymorphic loci are known in $I G F B P 3^{4,5}$; the A allele at the -202 locus has a significantly higher promoter activity compared with that of the $\mathrm{C}$ allele, which is consistent with the relationship observed between genotype and circulating IGFBP-3 
levels $(\mathrm{AA}>\mathrm{AC}>\mathrm{CC})^{5,6)}$. The frequency of the $\mathrm{C}$ allele at the $-202 \mathrm{~A} / \mathrm{C}$ polymorphism was $53.5 \%$ in a multiethnic population living in Canada ${ }^{5)}$ and 54\% in female registered nurses living in the United States ${ }^{7)}$.

IGFBP-3, by binding IGF-I, regulates the serum levels of free IGF-I and maintains the reservoir of IGF-I. This factor is also related to apoptosis. High serum levels of IGFBP-3 lower the risk of cancer, such as those of the breast ${ }^{8)}$, prostate $^{9)}, \operatorname{colorectal}^{10)}$, and lung ${ }^{11)}$; many studies of the relationship between IGFBP-3 and cancer risk are currently in progress. High serum levels of IGFBP-3 may also lead to relatively low serum levels of free IGF-I, which may cause a decreased response to growth hormone. It is unclear whether the $-202 \mathrm{~A} / \mathrm{C}$ polymorphism affects individual variation of normal growth in healthy children, or only abnormal growth in children with growth hormone deficiency or acromegaly. We previously reported that the frequency of the $\mathrm{C}$ allele at the -202 locus was $16.7 \%(18.4 \%$ in boys, $14.3 \%$ in girls), and that the CC genotype was absent in 33 Korean children with relatively short stature ${ }^{12)}$. Here, we investigated the association between the genotype at the -202 locus and growth in normal Korean children by increasing the sample size and including taller participants, building on our previous study.

\section{Materials and methods}

\section{Participants and samples}

We studied girls aged between 15 and 16 years who volunteered to undergo physical examination for a population census at the Seoul School Health Center in 2001. They were divided into 3 groups by their height percentiles: short stature (3rd-10th percentile, group 1), medium stature (50th percentile, group 2), and tall stature (90th-97th percentile, group 3), according to the 2007 growth reference for Korean children and adolescents by the Korean Pediatric Society and the Korea Centers for Disease Control and Prevention ${ }^{13)}$. In total, 150 girls were enrolled in this study, and each group consisted of 50 randomly selected girls. Of these, 4 girls were excluded because the genotypes could not be identified in the 3 and the serum IFG- 1 level could not be determined in the remaining one. Finally, 146 girls (48 girls in group 1; 49 in group 2; and 49 in group 3) were analyzed. This study has been approved by the Institutional Review Board of Hallym University Kangdong Sacred Heart Hospital, Seoul, Korea (approval number: KANGDONG 2015-03-012).

\section{Measurement of serum IGF-I and IGFBP-3 levels and extraction of DNA}

Blood samples ( $1 \mathrm{~mL}$ of whole blood and $2 \mathrm{~mL}$ of serum) were obtained from each participant and were immediately stored at $-20{ }^{\circ} \mathrm{C}$ until required for bioassays. Serum levels of IGF-I and IGFBP-3 were measured using an IRMA kit (DSL Inc., Webster, TX, USA), and genomic DNA was extracted from whole blood using a Wizard DNA Purification Kit (Promega, Madison, WI, USA) and stored at $-20{ }^{\circ} \mathrm{C}$ until required for analysis.

\section{PCR of /GFBP3 promoter region}

About 100 ng of genomic DNA was mixed with polymerase chain reaction (PCR) buffer, containing $1 \mu \mathrm{mol} / \mathrm{L}$ of sense primer, $1 \mu \mathrm{mol} / \mathrm{L}$ of antisense primer, $0.25 \mathrm{mmol} / \mathrm{L}$ of deoxyNTP, 1.25 U $h$-Taq DNA polymerase (SolGent, Seoul, Korea) and $5 \times$ Band Doctor (SolGent), and distilled water, to a total volume of $50 \mu \mathrm{L}$. The PCR cycling parameters consisted of an initial incubation of 15 minutes at $95^{\circ} \mathrm{C}$, followed by 35 cycles each consisting of 1 minute at $94{ }^{\circ} \mathrm{C}, 1$ minute at $64^{\circ} \mathrm{C}$, and 1 minute at $72{ }^{\circ} \mathrm{C}$. The reaction was terminated after a final extension of 10 minutes at $72^{\circ} \mathrm{C}$. The sense and antisense primer sequences were 5'-CCA CGA GGT ACA CAC GAA TG-3' and 5'-AGC CGC AGT GCT CGC ATC TGG-3', respectively ${ }^{5}$. Five microliters of PCR products were subsequently visualized on a $2 \%$ agarose gel stained with ethidium bromide.

\section{RFLP genotyping of the -202 locus}

After PCR, restriction fragment length polymorphism (RFLP) analysis was performed on the fragment to determine the genotype at the -202 IGFBP3 locus, as described in our previous study ${ }^{12)}$. Ten microliters of the PCR product were digested with 2.5 U Alw21I (MBI Fermentas, Flamborough, Canada), for $10-13$ hours at $37^{\circ} \mathrm{C}$, and samples were then incubated for 20 minutes at $65^{\circ} \mathrm{C}$ to inactivate the enzyme. Five microliters of the digestion product were visualized on a $2 \%$ agarose gel stained with ethidium bromide. Due to the presence of three Alw21I sites in the PCR product, one of which is destroyed by the presence of a $\mathrm{C}$ at the -202 locus, band sizes were 242 and 162 bp (A allele), and 288 and 162 bp (C allele) (Fig. 1).

\section{Statistical analysis}

In order to compare serum IGF-I and IGFBP-3 levels and the IGF-I/IGFBP-3 molar ratio according to genotype, an independent sample t-test and one-way analysis of variance were used. The chi-square test was used to compare the

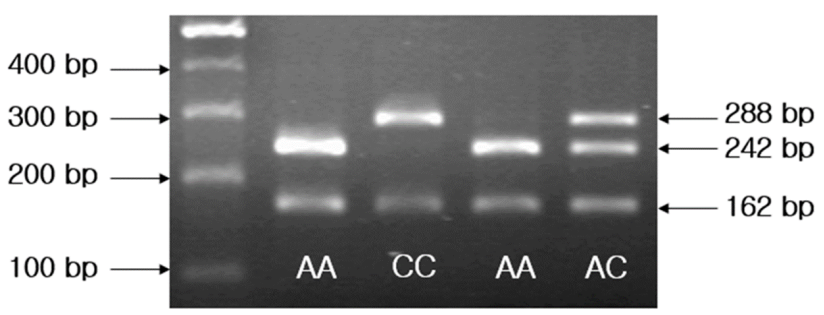

Fig. 1. A representative pattern of restriction fragment length polymorphism analysis on a gel indicates different genotypes in 4 individuals. A size marker (100-bp DNA ladder) is included in the far left lane. 
frequency of the genotypes. The data were analyzed using IBM SPSS Statistics ver. 19.0 (IBM Co., Armonk, NY, USA). A P-value $<0.05$ was used as the cutoff for statistical significance.

\section{Results}

\section{Distribution of genotypes and the frequency of alleles}

Among the 146 girls analyzed, the AA genotype was found in 79 girls (54.1\%), the AC genotype in 60 girls (41.1\%), and the CC genotype in 7 girls $(4.8 \%)$. In group $1(n=48)$, there were $29 \mathrm{AA}(60.4 \%), 17 \mathrm{AC}(35.4 \%)$, and $2 \mathrm{CC}$ genotypes (4.2\%). In group $2(\mathrm{n}=49), 23 \mathrm{AA}(47.0 \%), 25 \mathrm{AC}(51.0 \%)$, and $1 \mathrm{CC}$ genotypes (2.0\%) were found. In group $3(\mathrm{n}=49), 27$ girls had the AA (55.1\%), 18 the AC (36.7\%), and 4 the CC genotype $(8.2 \%)$. There was no statistical difference in genotype frequency between groups. The frequency of the C allele was 25.3\% (74 of 292 alleles); this included $21.9 \%$ ( 21 of 96 alleles) in group 1 , $27.6 \%$ (27 of 98 alleles) in group 2, and 26.5\% (26 of 98 alleles) in group 3. There was no statistical difference in the frequency of the $\mathrm{C}$ allele between groups, although the frequency of the $\mathrm{C}$ allele was somewhat lower in group 1.

\section{Analyses according to genotype}

1) Serum IGFBP-3 concentrations by genotype

The serum IGFBP- 3 concentration was $6,032 \pm 642 \mathrm{ng} / \mathrm{mL}$ in the AA genotype group, $5,670 \pm 722 \mathrm{ng} / \mathrm{mL}$ in the AC genotype group, and $5,214 \pm 893 \mathrm{ng} / \mathrm{mL}$ in the CC genotype group. In the AA genotype group, this concentration was significantly higher than in the AC and CC genotype groups (both $P=0.002$ ) (Fig. 2).

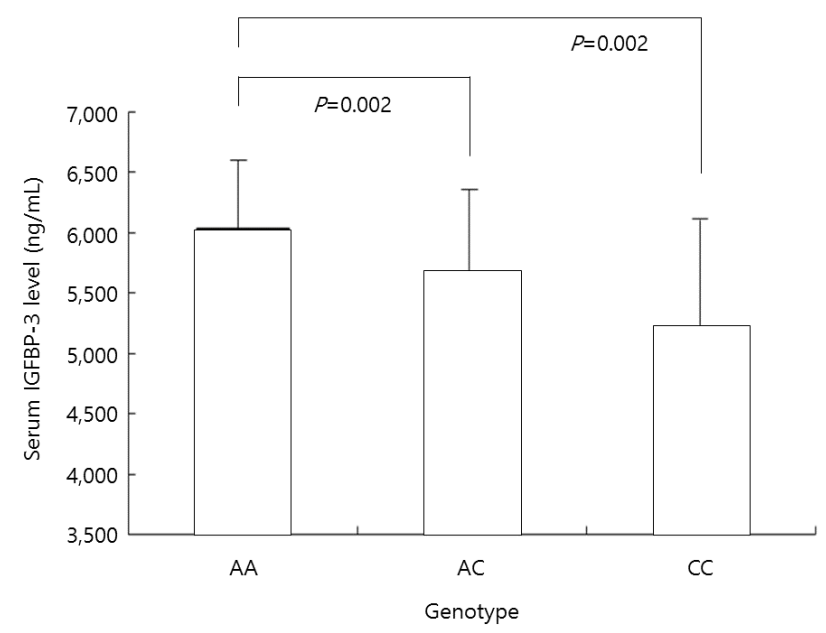

Fig. 2. Mean insulin-like growth factor-binding protein-3 (IGFBP-3) levels in all participants according to the genotype at nucleotide -202 of IGFBP-3. In the AA genotype group, this concentration was significantly higher than in the $A C$ and CC genotype groups (both $P=0.002$ ).

\section{2) The ratio of IGF-I/IGFBP-3}

The ratio of IGF-I/IGFBP-3 in the AA genotype group was $0.089 \pm 0.016$; in the $\mathrm{AC}$ genotype group this ratio was $0.096 \pm 0.018$, and that in the CC genotype group was $0.102 \pm 0.016$, respectively. The ratio was significantly lower in the AA genotype group than in the AC genotype group $(P=0.033)$ (Fig. 3).

\section{Analyses according to genotype in each group}

\section{1) Serum IGFBP-3 concentration}

The serum IGFBP- 3 concentrations in each group are summarized according to the genotype at the -202 locus in Table 1. In group 1, IGFBP-3 concentrations of the AA genotype group was $5,860 \pm 596 \mathrm{ng} / \mathrm{mL}$; in the AC genotype group, it was $5,463 \pm 594 \mathrm{ng} / \mathrm{mL}$, and in the CC genotype group, it was $4,476 \pm 153 \mathrm{ng} / \mathrm{mL}$. The IGFBP-3 concentration was significantly higher in the AA genotype group than in the AC genotype group $(P=0.035)$. In group 2 , the IGFBP-3 concentration of

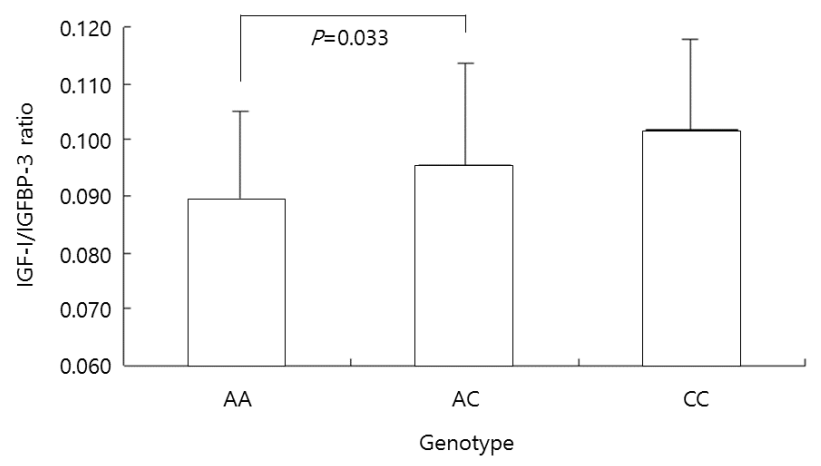

Fig. 3. The insulin-like growth factor-1 (IGF-I)//GF-binding protein-3 (IGFBP-3) ratio in all participants according to the genotype at the -202 A/C IGFBP3 locus. The ratio was significantly lower in the AA genotype group than in the $A C$ genotype group $(P=0.033)$.

Table 1. IGFBP-3 levels according to group and genotype at the $-202 \mathrm{~A} / \mathrm{C}$ locus

\begin{tabular}{lccc}
\hline Group & Genotype $(\mathrm{n})$ & $\mathrm{IGFBP}-3(\mathrm{ng} / \mathrm{mL})$ & $P$-value \\
\hline 1 (short) & AA (29) & $5,860 \pm 596$ & - \\
& AC (17) & $5,463 \pm 594$ & 0.035 \\
2 (medium) & CC (2) & $4,476 \pm 153$ & ND \\
& AA (23) & $6,079 \pm 707$ & - \\
& AC (25) & $5,669 \pm 686$ & 0.047 \\
3 (tall) & CC ( 1) & $5,113 \pm 000$ & ND \\
& AA (27) & $6,178 \pm 612$ & - \\
& AC (18) & $5,867 \pm 854$ & 0.161 \\
& CC (4) & $5,609 \pm 1,006$ & ND \\
\hline
\end{tabular}

Values are presented as mean \pm standard deviation.

Group 1, 3rd percentile $\leq$ height $<10$ th percentile; group 2, height $=50$ th percentile; group 3, 90th percentile $\leq$ height $<97$ th percentile; IGFBP-3, insulin-like growth factor-binding protein-3; ND; not determined.

a) $P$-values for IGFBP-3 levels within groups, AA vs. AC or CC. 
the AA genotype group was $6,079 \pm 707 \mathrm{ng} / \mathrm{mL}$, that in the AC genotype group was $5,669 \pm 686 \mathrm{ng} / \mathrm{mL}$, and that in the CC genotype group was $5,113 \pm 0 \mathrm{ng} / \mathrm{mL}$, respectively. The IGFBP-3 concentration was significantly higher in the AA genotype than in the AC genotype group $(P=0.047)$. In group 3, the IGFBP-3 concentration of the AA genotype group was $6,178 \pm 612 \mathrm{ng} / \mathrm{mL}$; the IGFBP-3 levels in the AC genotype group was $5,867 \pm 854 \mathrm{ng} /$ $\mathrm{mL}$, and that in the CC genotype group was $5,609 \pm 1,006 \mathrm{ng} / \mathrm{mL}$. IGFBP-3 levels between the AC genotype and AA genotype was not significantly different. Because the number of CC genotype was low in each group, statistical comparison between the CC genotype, AA genotype, and AC genotype was unfeasible.

2) The ratio of IGF-I/IGFBP-3

The IGF-I/IGFBP-3 ratio in each group is summarized

Table 2. IGF-I/IGFBP-3 ratio according to group and genotype at $-202 \mathrm{~A} / \mathrm{C}$ locus

\begin{tabular}{lccc}
\hline Group & Genotype $(\mathrm{n})$ & IGF-I/IGFBP-3 & $P$-value \\
\hline 1 (short) & AA (29) & $0.085 \pm 0.015$ & - \\
& AC (17) & $0.089 \pm 0.021$ & 0.461 \\
2 (medium) & CC (2) & $0.099 \pm 0.034$ & $\mathrm{ND}$ \\
& AA (23) & $0.093 \pm 0.016$ & - \\
3 (tall) & AC (25) & $0.097 \pm 0.017$ & 0.403 \\
& CC ( 1) & $0.097 \pm 0.000$ & ND \\
& AA (27) & $0.091 \pm 0.016$ & - \\
& AC (18) & $0.100 \pm 0.017$ & 0.072 \\
\hline
\end{tabular}

Values are presented as mean \pm standard deviation.

Group 1, 3rd percentile $\leq$ height $<10$ th percentile; group 2, height $=$ 50th percentile; group 3, 90th percentile $\leq$ height $<97$ th percentile.

IGF-I, insulin-like growth factor-1; IGFBP-3, IGF-binding protein-3; ND; not determined.

a) $P$-values for IGF-I/IGFBP-3 within groups, AA vs. AC or CC. according to the genotype at the -202 locus in Table 2. In group 1 , the IGF-I/IGFBP-3 ratio of the AA genotype group was $0.085 \pm 0.015$; that in the AC genotype group was $0.089 \pm 0.021$, and that in the CC genotype group was $0.099 \pm 0.034$. There was no significant difference in the IGF-I/IGFBP-3 ratio between the $\mathrm{AA}$ and $\mathrm{AC}$ genotype groups $(P=0.461)$. In group 2, the IGF-I/ IGFBP-3 ratio of the AA genotype group was $0.093 \pm 0.016$; in the AC genotype group, it was $0.097 \pm 0.017$, and in the CC genotype group, it was $0.097 \pm 0.000$, respectively. There was no significant difference between the AA and AC genotype groups in terms of the IGF-I/IGFBP-3 ratio $(P=0.403)$. In group 3 , the IGF-I/IGFBP-3 ratio was $0.091 \pm 0.016,0.100 \pm 0.017$, and $0.105 \pm 0.010$, in the AA, AC, and CC genotype groups, respectively. There was also no significant difference in this ratio between the AA genotype and AC genotype groups in group $3(P=0.072)$. Because there were only few CC homozygotes in each group, a statistical comparison between the CC genotype and the other genotypes was not possible.

\section{Analyses according to group (Fig. 4)}

\section{1) Serum IGF-I concentration}

The IGF-I concentration was $494 \pm 110 \mathrm{ng} / \mathrm{mL}$ in group 1 , $559 \pm 133 \mathrm{ng} / \mathrm{mL}$ in group 2 , and $572 \pm 112 \mathrm{ng} / \mathrm{mL}$ in group 3. IGF-I concentrations in groups 2 and 3 were significantly higher than in group $1(P=0.011$ and $P=0.001)$. There was no significant difference in these levels between groups 2 and 3 $(P=0.583)$.

\section{2) Serum IGFBP-3 concentration}

The IGFBP-3 concentration was $5,662 \pm 656 \mathrm{ng} / \mathrm{mL}$ in group $1,5,850 \pm 719 \mathrm{ng} / \mathrm{mL}$ in group 2 , and $6,017 \pm 749 \mathrm{ng} / \mathrm{mL}$ in group 3. The IGFBP-3 concentration was significantly higher in group
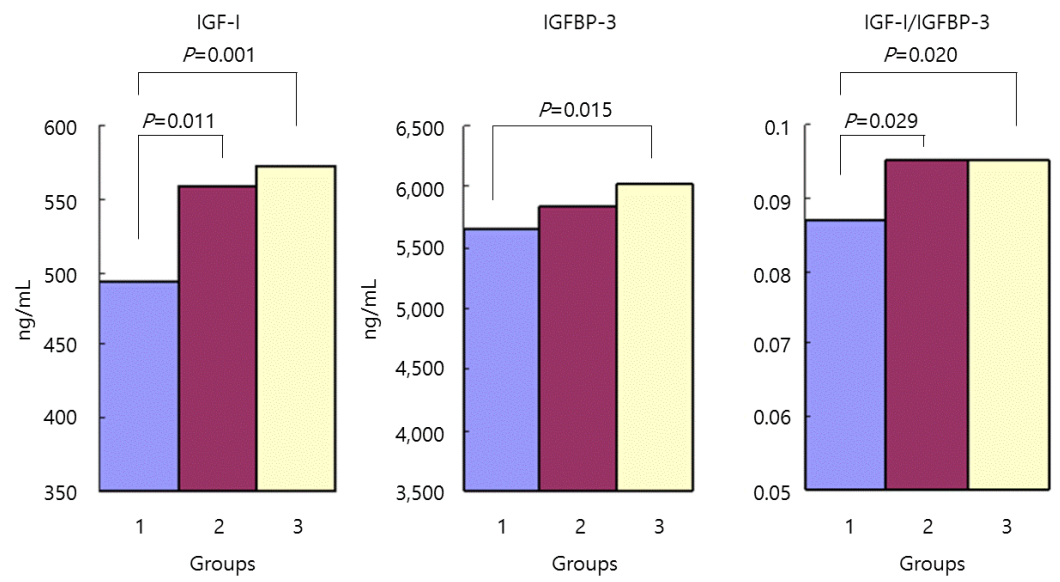

Fig. 4. Mean levels of insulin-like growth factor-1 (IGF-I), IGF-binding protein-3 (IGFBP-3), and IGF-I/ IGFBP-3 ratio were compared according to group. IGF-I concentrations in groups 2 and 3 were significantly higher than in group 1 ( $P=0.011$ and $P=0.001$ ). The IGFBP-3 concentration was significantly higher in group 3 than in group $1(P=0.015)$. The IGF-I/IGFBP-3 ratio was significantly higher in groups 2 and 3 than in group 1 ( $P=0.029$ and $P=0.020$ ). Group 1, 3rd percentile $\leq$ height $<10$ th percentile; group 2, height $=50$ th percentile; group 3, 90th percentile $\leq$ height $<97$ th percentile. 
3 than in group $1(P=0.015)$. There was no significant difference between groups 1 and 2 , or between groups 2 and 3 .

\section{3) The ratio of IGF-I/IGFBP-3}

In group 1 , the IGF-I/IGFBP-3 ratio was $0.087 \pm 0.018$. In group 2 , this ratio was $0.094 \pm 0.016$, and in group 3 , it was $0.095 \pm 0.016$. The IGF-I/IGFBP- 3 ratio was significantly higher in groups 2 and 3 than in group $1(P=0.029$ and $P=0.020)$. There was no significant difference between groups 2 and $3(P=0.878)$.

\section{Discussion}

The CC genotype was not found in the participants of our preliminary study ${ }^{12}$. We had assumed that this was due to sampling error, but in the present study, the CC genotype was also present at a frequency of only $4.8 \%$ (7 out of 146) in the whole group. This was consistent with the results of other studies of Korean adults ${ }^{14,15)}$. In previous studies, the frequency of the C allele was $53.5 \%$ in US adults ${ }^{5)}, 54.0 \%$ in US women alone $^{7}, 51.5 \%$ in males and $54.7 \%$ in females from the $\mathrm{UK}^{16)}$, $19.2 \%$ in Chinese women ${ }^{17)}$, and $24.8 \%$ in Japanese men ${ }^{18)}$. In our previous study ${ }^{12)}$, the frequency of the $\mathrm{C}$ allele in 33 Korean children was $16.7 \%$ (boys, 18.4\%; girls, $14.3 \%$ ), while in this study, the frequency of the $\mathrm{C}$ allele was $25.4 \%$. This indicates ethnic and racial differences, and that the frequency of the $\mathrm{C}$ allele was higher in white people than in East Asians. If the $\mathrm{C}$ allele reduces the serum concentration of IGFBP-3, it can be assumed that the serum concentration of free IGF-I can be relatively elevated in the presence of the $\mathrm{C}$ allele. A higher number of $\mathrm{C}$ alleles are likely to lead to greater stature, and may therefore be a factor affecting the height difference between white people and East Asians. There are numerous studies on the relationship between the $-202 \mathrm{~A} / \mathrm{C}$ promoter polymorphism in IGFBP3 and cancer risk. However, only a few studies were conducted about the relationship with childhood growth.

Expressions of IGF-I and IGFBP-3 are controlled by growth hormone and these factors are important substances for growth. In particular, because the concentration of free IGF-I is affected by the concentration of IGFBPs, including IGFBP-3, the polymorphism at position - 202 of the IGFBP3 promoter, which affects the concentration of IGFBP- $3^{5,6)}$, is thought to have an impact on growth. In a preliminary study, the A allele did not increase the serum concentration of IGFBP-3, compared to the C allele ${ }^{12)}$. However, in this study, a higher serum concentration of IGFBP-3 was observed in medium and short stature individuals with the AA genotype compared to those with the AC genotype, as seen in previous reports ${ }^{5,6,19)}$.

In children, growth hormone has a significant impact on growth from before puberty, and drives growth with sex hormones in adolescence. In serum, about $75 \%$ of IGF is present in the form of a $150-200 \mathrm{kDa}$ complex, and consists of $7.5 \mathrm{kDa}$ IGF-I/IGF-II, 38-43 kDa IGFBP-3, and 80-90 $\mathrm{kDa}$ acid-labile subunits ${ }^{20)}$. When combined with IGFBP-3, it forms a large complex, which cannot pass through the vascular endothelial barrier and it becomes a repository by which the half-life of IGF is extended ${ }^{21)}$. Complexes of $40-50 \mathrm{kDa}$ in size account for $20 \%-25 \%$ of the total IGF, and may act on the local tissue through the endothelial barrier. Serum IGFBP controls endocrinal effects by regulating the amount of activated IGF, such as $50-\mathrm{kDa}$ IGF and free IGF. In local tissue, the presence of IGFBP implies that it has a local paracrine or autocrine effect on the regulation of IGF actions ${ }^{22-24)}$.

In this study, although we did not measure the concentration of free IGF-I, we measured this indirectly by calculating the IGF-I/IGFBP-3 ratio, and compared this in the various genotype groups. However, the ratio of IGF-I/IGFBP-3 did not differ according to genotype in any of the groups. A previous report found an association of the ratio between IGF-I and IGFBP-3, and showed that the concentration of IGFBP-3 differed significantly depending on the genotype, even though the ratio between IGF-I and IGFBP- 3 was not different ${ }^{25}$. These findings are consistent with the results of our own study. These studies indicate that variation at the -202 IGFBP3 locus does not have a direct effect on the serum concentration of IGF-I and free IGF-I levels. Although it is clear that the serum concentration of IGFBP- 3 is affected by the alleles of the -202 locus, it was significantly higher in the tall stature group than in the short stature group; it was also higher in the medium stature group than in short stature group, although not statistically significantly so. Considering these data, it is plausible that other factors play a greater role in the individual variation in body height. In addition, because differences in serum IGF-I concentration was seen between groups, and as the ratio of IGF-I/IGFBP-3 is more affected by IGF-I concentration, it is likely that IGF-I has a greater effect on height differences than IGFBP-3.

Until the early 1970s, according to the original somatomedin theory, which holds that growth hormone promotes IGF-I production in the liver, rather than affecting growth directly, and affects longitudinal bone growth via an endocrinal effect, was accepted as dogma ${ }^{26)}$. However, from the 1980s, IGF-I was found to be produced not only in the liver, but also in many tissues ${ }^{27,28)}$. In the early 2000s, it was found that growth hormone is involved in the process of chondrocytes bulb (prechondrocyte) differentiation and cell division, and that IGF-I has autocrine and paracrine effects ${ }^{29)}$ and IGF-I from differentiated cells or cells surrounding prechondrocytes cause expansion of clones. It is called dual effector theory ${ }^{30}$. However, IGF-I promotes longitudinal bone growth by 'insulin-like' anabolic actions that enhance chondrocyte hypertrophy in IGF-1-null mice, which cannot be explained only by that theory ${ }^{31)}$. The source of IGF-I that promotes the thickening of chondrocytes was uncertain, but because IGFI mRNA is expressed in the periosteum, muscle, and adipocytes, these may be a good source of the growth in bony length growth. In mice in which IGF-I production in the liver is abolished, the concentration of IGF-I in the serum was reduced by $75 \%$. However, the reduction in serum IGF-I level had no discernible effect on postnatal body growth. This suggested that liver-derived IGF-I is the main determinant of serum IGF-I, but is not required for postnatal growth, indicating 
that autocrine/paracrine-produced IGF-I is more important than liver-derived IGF-I for body growth ${ }^{32)}$.

Additional information of the participants' parental heights could have provided a more accurate analysis of the study but the samples were obtained from a national census study, which recorded only general physical information of the participants' heights and additional information regarding puberty, such as breast budding age, time of menarche was not reflected. As less than 5\% of the participants showed CC genotypes, statistical analysis was not performed for that specific genotype, when the study population was subdivided by varying heights. As mentioned earlier, free IGF-I, IGF-I, and IGFBP-3 levels in serum cannot reflect the concentration of IGF-I and IGFBP- 3 in local tissue, particularly in the growth plate. In this respect, the autocrine and paracrine effects of IGF-I from extrahepatic tissue and the measurement of its level in target tissue, particularly in the growth plate, should be studied.

In conclusion, the -202 polymorphism in the IGFBP3 promoter region is assumed to affect the serum concentration of IGFBP-3 in children as well as in adults. However, it is unclear whether it affects physical development according to the concentration of IGFBP-3. In addition, because the frequency of the $\mathrm{C}$ allele was shown to differ between ethnic and racial groups, further studies of the role of this polymorphism should be conducted.

\section{Conflict of interest}

No potential conflict of interest relevant to this article was reported.

\section{References}

1. Daughaday WH, Rotwein P. Insulin-like growth factors I and II. Peptide, messenger ribonucleic acid and gene structures, serum, and tissue concentrations. Endocr Rev 1989;10:68-91.

2. Blum WF, Albertsson-Wikland K, Rosberg S, Ranke MB. Serum levels of insulin-like growth factor I (IGF-I) and IGF binding protein 3 reflect spontaneous growth hormone secretion. J Clin Endocrinol Metab 1993;76:1610-6.

3. Juul A, Dalgaard P, Blum WF, Bang P, Hall K, Michaelsen KF, et al. Serum levels of insulin-like growth factor (IGF)-binding protein-3 (IGFBP-3) in healthy infants, children, and adolescents: the relation to IGF-I, IGF-II, IGFBP-1, IGFBP-2, age, sex, body mass index, and pubertal maturation. J Clin Endocrinol Metab 1995;80:2534-42.

4. Sun G, Chagnon M, Bouchard C. A common polymorphism in the human insulin-like growth factor binding protein 3 gene. Mol Cell Probes 2000;14:55-6.

5. Deal C, Ma J, Wilkin F, Paquette J, Rozen F, Ge B, et al. Novel promoter polymorphism in insulin-like growth factor-binding protein-3: correlation with serum levels and interaction with known regulators. J Clin Endocrinol
Metab 2001;86:1274-80.

6. Jernström H, Deal C, Wilkin F, Chu W, Tao Y, Majeed $\mathrm{N}$, et al. Genetic and nongenetic factors associated with variation of plasma levels of insulin-like growth factor-I and insulin-like growth factor-binding protein-3 in healthy premenopausal women. Cancer Epidemiol Biomarkers Prev 2001;10:377-84.

7. Schernhammer ES, Hankinson SE, Hunter DJ, Blouin MJ, Pollak MN. Polymorphic variation at the -202 locus in IGFBP3: Influence on serum levels of insulin-like growth factors, interaction with plasma retinol and vitamin D and breast cancer risk. Int J Cancer 2003;107:60-4.

8. Hankinson SE, Willett WC, Colditz GA, Hunter DJ, Michaud DS, Deroo B, et al. Circulating concentrations of insulin-like growth factor-I and risk of breast cancer. Lancet 1998;351:1393-6.

9. Chan JM, Stampfer MJ, Giovannucci E, Gann PH, Ma J, Wilkinson P, et al. Plasma insulin-like growth factor-I and prostate cancer risk: a prospective study. Science 1998;279:563-6.

10. Ma J, Pollak MN, Giovannucci E, Chan JM, Tao Y, Hennekens $\mathrm{CH}$, et al. Prospective study of colorectal cancer risk in men and plasma levels of insulin-like growth factor (IGF)-I and IGF-binding protein-3. J Natl Cancer Inst 1999;91:620-5

11. Yu H, Spitz MR, Mistry J, Gu J, Hong WK, Wu X. Plasma levels of insulin-like growth factor-I and lung cancer risk: a case-control analysis. J Natl Cancer Inst 1999;91:151-6.

12. Choi WJ, Yang S, Im JH, Lee YI, Shin JH. the relationship between insulin-like growth factor binding protein-3 promoter polymorphism and growth. J Korean Soc Pediatr Endocrinol 2006;11:28-32.

13. Moon JS, Lee SY, Nam CM, Choi JM, Choe BK, Seo JW, et al. 2007 Korean National Growth Charts: review of developmental process and an outlook. Korean J Pediatr 2008;51:1-25.

14. Park JS, Chang YS, Yoo KN, Nam JY, Kim CS, Kim DM, et al. Relations between IGFBP-3 promoter polymorphism and body composition parameters and obesity. J Korean Soc Study Obes 2004;13:187-94.

15. Moon JW, Chang YS, Ahn CW, Yoo KN, Shin JH, Kong JH, et al. Promoter -202 A/C polymorphism of insulin-like growth factor binding protein-3 gene and non-small cell lung cancer risk. Int J Cancer 2006;118:353-6.

16. Al-Zahrani A, Sandhu MS, Luben RN, Thompson D, Baynes C, Pooley KA, et al. IGF1 and IGFBP3 tagging polymorphisms are associated with circulating levels of IGF1, IGFBP3 and risk of breast cancer. Hum Mol Genet 2006;15:1-10.

17. Ren Z, Cai Q, Shu XO, Cai H, Li C, Yu H, et al. Genetic polymorphisms in the IGFBP3 gene: association with breast cancer risk and blood IGFBP-3 protein levels among Chinese women. Cancer Epidemiol Biomarkers Prev 2004;13:1290-5.

18. Wang L, Habuchi T, Tsuchiya N, Mitsumori K, Ohyama C, 
Sato K, et al. Insulin-like growth factor-binding protein-3 gene $-202 \mathrm{~A} / \mathrm{C}$ polymorphism is correlated with advanced disease status in prostate cancer. Cancer Res 2003;63:440711.

19. van der Kaay DC, Hendriks AE, Ester WA, Leunissen RW, Willemsen RH, de Kort SW, et al. Genetic and epigenetic variability in the gene for IGFBP-3 (IGFBP3): correlation with serum IGFBP-3 levels and growth in short children born small for gestational age. Growth Horm IGF Res 2009;19:198-205.

20. Mohan S, Baylink DJ, Pettis JL. Insulin-like growth factor (IGF)-binding proteins in serum--do they have additional roles besides modulating the endocrine IGF actions? J Clin Endocrinol Metab 1996;81:3817-20.

21. Zapf J. Physiological role of the insulin-like growth factor binding proteins. Eur J Endocrinol 1995;132:645-54.

22. Rajah R, Valentinis B, Cohen P. Insulin-like growth factor (IGF)-binding protein-3 induces apoptosis and mediates the effects of transforming growth factor-betal on programmed cell death through a p53- and IGFindependent mechanism. J Biol Chem 1997;272:12181-8.

23. Clemmons DR. Role of insulin-like growth factor binding proteins in controlling IGF actions. Mol Cell Endocrinol 1998;140:19-24.

24. Baxter RC. Insulin-like growth factor (IGF)-binding proteins: interactions with IGFs and intrinsic bioactivities. Am J Physiol Endocrinol Metab 2000;278:E967-76.

25. Slattery ML, Baumgartner KB, Byers T, Guiliano A, Sweeney C, Herrick J, et al. Genetic, anthropometric, and lifestyle factors associated with IGF-1 and IGFBP-3 levels in
Hispanic and non-Hispanic white women. Cancer Causes Control 2005;16:1147-57.

26. Daughaday WH, Hall K, Raben MS, Salmon WD Jr, van den Brande JL, van Wyk JJ. Somatomedin: proposed designation for sulphation factor. Nature 1972;235:107.

27. D'Ercole AJ, Applewhite GT, Underwood LE. Evidence that somatomedin is synthesized by multiple tissues in the fetus. Dev Biol 1980;75:315-28.

28. Roberts CT Jr, Lasky SR, Lowe WL Jr, Seaman WT, LeRoith D. Molecular cloning of rat insulin-like growth factor I complementary deoxyribonucleic acids: differential messenger ribonucleic acid processing and regulation by growth hormone in extrahepatic tissues. Mol Endocrinol 1987;1:243-8.

29. Butler AA, LeRoith D. Minireview: tissue-specific versus generalized gene targeting of the igf 1 and igflr genes and their roles in insulin-like growth factor physiology. Endocrinology 2001;142:1685-8.

30. Ohlsson C, Bengtsson BA, Isaksson OG, Andreassen TT, Slootweg MC. Growth hormone and bone. Endocr Rev 1998;19:55-79.

31. Wang J, Zhou J, Bondy CA. Igfl promotes longitudinal bone growth by insulin-like actions augmenting chondrocyte hypertrophy. FASEB J 1999;13:1985-90.

32. Sjögren K, Liu JL, Blad K, Skrtic S, Vidal O, Wallenius V, et al. Liver-derived insulin-like growth factor I (IGF-I) is the principal source of IGF-I in blood but is not required for postnatal body growth in mice. Proc Natl Acad Sci U S A 1999;96:7088-92. 